The Geneva Papers on Risk and Insurance, 20 (No. 77, October 1995) 504-508

\title{
Investing in Emerging Markets: What Lessons Can we Learn from the Recent Unstable Period?*
}

\author{
by Antoine Jeancourt-Galignani**
}

\section{Introduction}

Investment in emerging markets grew considerably during the past few years. The principal beneficiaries were the countries of Asia and Latin America, but also Mediterranean countries and even some African countries.

According to the Institute of International Finance, total equity investments in these countries came to USD 88 billion in 1993 and USD 82 billion in 1994, while in 1988 they scarcely even reached the USD 15 billion mark. The most notable capital resource movement was financial investment in issues launched in these countries. The annual flow of portfolio equity investment, for example, culminated in 1993 at USD 50 billion, compared with less than USD 5 billion before 1989. Investments in debt securities purchased by non-banking institutions exceeded USD 69 billion for 1993, and again hit USD 48 billion in 1994, having come from less than USD 10 billion in 1988-1989. Underlying this exceptional growth in capital flows were an increase in both the number of transactions and in their unit value. Thus, in September 1994, the MSCI index for emerging countries neared 430, having hovered in the 100 range at the start of 1988.

A clear shift in tendency, and especially in anticipations, was marked in the early days of 1994. The raising of U.S. interest rates at the beginning of February; Mexico's political unrest, caused by the guerrilla activity in the southern part of that country and above all by the March assassination of the official Presidential candidate, precipitated a stock market fall and a sharp contraction of capital movements. The MSCI index fell 15 percent during the first four months of the year and the Brady bond index dropped by more than 20 percent.

The Asian stock markets also experienced a sharp fall tied in part to new worries over China, its political direction and its willingness to honor trade agreements. Still, the second half saw a recovery in most emerging markets, with the indices surpassing the heights attained at the end of 1993.

* Text presented at the 22nd General Assembly of the Geneva Association, Lisbon, May 26, 1995.

** President and Chief Executive of AGF, Assurances Générales de France, Paris. 
The real blow came with the Christmas 1994 debt payment crisis in Mexico. Its shock sent all emerging country stock market indices in a headlong fall, touching off a strong flight of capital out of these countries, especially from Latin America. The first months of 1995 witnessed a modest recovery in Asian stock markets, but investors remain reticent. Capital flows will not soon return to their 1993 and 1994 levels. According to the IIF, the total amount of capital invested in emerging countries should fall to USD 63 billion in 1995 . Above all, it is expected that non-banking establishments will withdraw USD 5 billion net from their investments in the debt securities of these countries.

What lesson can the European investor draw from this brief experience in the emerging markets? What should such an investor's attitude be toward such investments, and how should one organize to manage them?

The development of emerging countries will be a long and tumultuous adventure whose ups and downs and shocks can be predicted by no one. It is possible, however, to suggest to the investor a few guidelines.

\section{Emerging markets are now an integral part of the global financial landscape, and the investor would weaken his position by ignoring them.}

It is the reality of their economic growth that forces these countries into our economic and financial range of vision. These countries are now adepts of the capitalistic, marketoriented economic model and of the advantages offered by division of labor on the world scale. The majority of them are today on the road toward economic gain and will therefore, on the avarage, experience growth rates far in excess of those enjoyed by the developed industrial world. In most of these countries on the march toward development, economic growth is accompanied by policies of more or less rapid financial liberalization, matched by the establishment and growth of financial markets that are more and more welcoming to foreign investors.

In many of these countries, the local people, and especially the new upper-middle and upper classes are very attracted to the local stock markets, all the more so as they have traditionally preferred to invest their savings nearby. This is the case for Asians, and especially for the overseas Chinese community. In Latin America, the local stock markets have attracted back capital that had fled these countries in the early 1980's. In any case, it is striking that economic development everywhere gets a boost from a certain taste for speculative risk, a taste that is probably more natural in these countries than it was in our European societies at the same stage of development. This explains for example why equities markets often develop more rapidly than public sector bond markets, even though the opening of the latter to foreign investors obviously poses fewer political problems than does foreign equity investment in local private enterprise. This local preferred taste for equity risk is seen in China and in Thailand, for example, despite these countries' significant public sector financing requirements.

\section{Institutional savings management as currently practiced in developed countries will inevitably lead to a more lasting interest in emerging markets.}

Institutional savings management is today handled on a global and extremely competitive basis. The large American and British investment vehicles, amassing the largest sums, are managed by professional investors who are now well-equipped to seek out every 
investment opportunity that could enable them to beat the competition. By training, they now have a very global view of the world marketplace. They can also be counted on to remain very alert to each growth opportunity offered by the full spectrum of world stock markets, especially those that appear to be in a turnaround situation.

This management approach has been facilitated by the development of more and more sophisticated research and trading tools in the emerging countries themselves, by the creation through brokers specialized in such risks, and by the large American brokerage houses, of networks covering all these countries.

On the other hand, the very operation of this British-American industrial investment approach can accentuate the risks of volatility and illiquidity inherent in these markets. For its business logic leads to pouring relatively massive amounts of investment into these often narrow markets. When such investments are financed by debt, as is the case with the hedge funds, the risk of wide and sudden price and liquidity swings becomes readily apparent. It will be interesting in this regard to observe the attitude of banks toward the hedge funds, and in particular toward those multipliers of credit that they will have authorized to those who intervene mainly on the emerging markets.

\section{Recent history teaches that investments carry risks; but clearly there are several different types of risk.}

4.1. Certain countries expose the investor to high risks, and the fashion of investing in emerging countries dulled them to the risks until 1994's rude awakening. Such countries are the ones whose financial infrastructure development reflects obvious excesses:

- excess indebtedness to Gross Domestic Product, or overloaded debt/export ratios;

- excessive national currency valuations, bloated by the inflow of foreign capital; and

- excess of foreign investment in relation to local investment-absorption capacity.

For the past several years, Mexico exhibited all the symptoms of these excesses. It doesn't stretch reality to say that it is a bit the same for Argentina.

Other imbalances can appear between the volume of savings ready to be invested in a given stock market and the number of businesses capable of providing the information, structures, and performance necessary to satisfy such investment. This was the typical situation in 1993-1994 for China where initial public offerings being put together by western investment houses for the Shanghai market far exceeded the management resources of the businesses concerned.

4.2. These investments also run systemic risks to the degree that today investment analysts have settled on the concept of emerging market investments as an investment category. It was for this reason that last December's Mexican debt crisis precipitated drops in stock prices in financial markets far removed from Mexico.

What are the chances that this concept will survive? One thing is certain, in the future analysts and investors alike will tend to distinguish between different country groupings, and particularly between Asia, Latin America, and Africa. Nevertheless, for some more time, emerging countries will constitute an amalgam whose stock market performances will remain correlated. The consequent risk of market volatility is all the greater today in that most international investment in emerging countries comes from non-bank sources of capital. 
The reason for this is that most banks still remember the lessons learned from their own excesses during the 1970's and are not inclined to lend comparable amounts to developing countries. Now, in terms of stability, bank loans are much less transportable than securities investments. Today, investors are directly exposed to the emerging markets through financial instruments that they might be tempted to remove on short notice, thus compounding the price variations of these instruments and the swings in market liquidity.

\section{To operate in these markets, the investor must therefore obtain the help of well- informed professionals}

Such professionals are investment managers and analysts specialized in the emerging markets or in one or another subcategory of market. The wealthiest investors can afford to house such specialists within their walls; the others will find them in outside investment firms. The performance of these managers during the 1994-1995 period will be a good indicator of their lucidity and foresight.

In a more general way, such investment managers must know these countries well and be able to combine their technical analysis of the market with a minimum of reflection on the national economic environment in which that market evolves. By all accounts, this was the weak point of investment management applied to emerging markets over the last few years. Perhaps investors should require that their asset managers, whether in-house or on the outside, subject themselves to the lessons to be learned from economists specialized in tracking these countries, such as those at the Institute of International Finance in Washington. They at least remained lucid over Mexico's outlook during the last few years, and had the prescience to issue several warnings on the subject.

Such managers must also be familiar with the markets' many compartments, and not overlook the debt market. This latter can sometimes offer quite interesting opportunities, as was the case with the Brady bonds during the most recent period when their price fell below that of the collateral backing their redemption. On such occasions quite attractive arbitrage opportunities can open up.

Of course, as with all investment activity, the timing of decisions is of the utmost importance for determining profit. The economists of Swiss Bank Corporation were able to show that an investment in emerging markets between 1988 and 1993, if sufficiently diversified, presented lower risk and higher profit than a comparable investment on the developed markets. It is certain that an investment manager who in early 1994 had cut far back on exposure to the emerging markets would have substantially optimized investment yields. Still, forecasting market reversals is one of the most difficult of the financial arts, especially when hard-to-predict political accidents spring up. Such was the case with Mexico.

\section{Investment in an emerging market presents the European investor a particular dif- ficulty, that is very much tied to the U.S. dollar.}

In effect, the currencies of Asian countries outside Japan, like those of Latin America, are very much tied to the dollar. Certain Asian countries, such as Singapore and Taiwan, have cautiously attempted to revalue their currencies in the wake of the strong yen. As is seen clearly in Argentina and Chile, the countries of Latin America are now setting their sights on achieving currency stability vis-à-vis the dollar, but it is not easy. 
In any case, the currency fluctuations of these countries are far removed from the exchange rate movements of the strong currencies of Europe. This is all the more the case since a number of investment instruments in the emerging countries are denominated in the dollar.

For this reason, therefore, in terms of investment timing, the investment manager for the European investor must take into account likely variations during the period between the investor's home currency and the dollar.

\section{Conclusions}

Investment in new countries is not an entirely novel activity for our old companies. We have already underwritten exotic issues, and our forefathers joined in the development of Russia and China at the beginning of the century. Today's phenomenon, however, takes on an aspect that is quite new in terms of its vastness; moreover, emerging market investment is part of a globalization of the world economy that compels investors to follow. Beyond this, it entails a great variety of financial instruments, and mobilizes the backing of numerous professionals.

Just as easily, investors will now live with the risks and opportunities of investing a portion of their portfolios in these countries. To do so they will have to equip themselves, and especially they will have to acquire a culture that enables them to track these investments more effectively.

They will also have to understand that investments in the developed world, and hence in their own companies, will from now on be in competition with those of these new countries. Investors will have to understand also that the security they associate with these familiar, home-country investments will not seem enough, at times, to compensate the attraction of the high returns generated by investments in the younger, more rapidly growing nations. 